KEBERPIHAKAN GEREJA

TERHADAP ORANG DENGAN GANGGUAN JIWA (ODGJ)

\author{
Oleh: Wilfridus F. Beo Dey
}

\begin{abstract}
Abstrak:
Artikel ini bertujuan untuk menemukan pandangan Gereja dan gagasan-gagasan mengenai kebijakan pastoral yang mungkin sebagai upaya untuk mengurus dan mengatasi problem Orang Dengan Gangguan Jiwa (ODGJ). Pendekatan yang digunakan dalam tulisan ini adalah pendekatan kualitatif melalui studi kepustakaan. Penulis akan mendalami pandanganpandangan Gereja tentang manusia teristimewa manusia yang sedang mengalami gangguan jiwa, lalu dilanjutkan dengan mengemukakan gagasan tentang kebijakan pastoral yang mungkin dalam mengurus dan mengatasi problem Orang Dengan Gangguan Jiwa (ODGJ). Hasil yang mau dicapai yakni agar semua umat dan keluarga ODGJ terbebas dari stigma pasung dan para ODGJ bisa dirawat dengan aturan standar kesehatan.
\end{abstract}

Kata-kata kunci: Orang Dengan Gangguan Jiwa (ODGJ), Gereja, Umat Beriman, Pastoral.

\title{
I. Pengantar
}

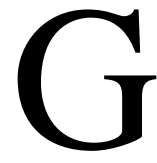
angguan kejiwaan yang menimpa manusia adalah problem universal. Data World Health Organisation (WHO) tahun 2016 mencatat terdapat sekitar 35 juta orang terkena depresi, 60 juta orang terkena bipolar, 21 juta terkena skizofrenia, sekitar 47,5 juta terkena dimensia. Di Indonesia dengan berbagai faktor biologis, psikologis dan sosial dengan keanekaragaman penduduk, maka jumlah kasus gangguan jiwa terus bertambah yang berdampak pada penambahan beban negara dan penurunan produktifitas manusia untuk jangka Panjang. Data Riset Kesehatan Dasar (Riskesdes) tahun 2013 menunjukkan prevalensi gangguan mental emosional yang ditunjukkan dengan gejala-gejala depresi dan kecemasan untuk usia 15 tahun ke atas mencapai sekitar $6 \%$ dari jumlah penduduk Indonesia atau sekitar 14 juta jiwa (Biro Komunikasi dan Pelayanan Masyarakat, Kemenkes RI, 2016).

Data di atas memperlihatkan bahwa jumlah penduduk yang terkena ganguan kejiwaan dengan pelbagai tipe dan jenis cukup banyak. Jumlah ini menuntut perhatian serius dari segenap eleman bangsa dan tidak hanya direduksi sekedar masalah pemerintah atau masalah domestik dari keluarga yang anggotanya mengalami gangguan kejiwaan. Peran lembaga swasta baik yang bernaung di bawah lembaga keagamaan maupun lembaga sosial lainnya diharapkan bisa menunjang program pemerintah dalam mengentaskan problem gangguan kejiwaan. Pada karya tulis ini penulis akan mengemukakan bagaimana peran Gereja sebagai salah satu lembaga keagamaan dalam menanggulangi masalah kesehatan jiwa. Gereja pasti menyadari bahwa 
panggilannya di dunia adalah panggilan yang diperuntukkan bagi semua orang termasuk kepada Orang Dengan Gangguan Jiwa (selanjutnya disingkat ODGJ). Gereja diharapkan memiliki pandangan sekaligus sikap nyata dalam bentuk gerakan kepedulian terhadap ODGJ dan lebih dari itu dapat diterjemahkan ke dalam kebijakan pastoral.

Dalam kaitan dengan menemukan pandangan dan sikap Gereja terhadap ODGJ maka penulis akan memfokuskan kajian pada pandangan biblis dan ajaran-ajaran Gereja resmi Gereja tentang martabat pribadi manusia untuk menemukan intisari pandangan dan sikap yang semestinya dari Gereja terhadap ODGJ. Beberapa kajian kepustakaan baik dari Kitab Suci dan ajaran resmi Gereja akan digunakan untuk mendalami problem ODGJ.

\section{Gereja dan Problem Orang dengan Gangguan Jiwa (ODGJ)}

Pertanyaan pokok yang ingin didalami adalah bagaimana Gereja mesti bergiat mengatasi masalah Orang dengan Gangguan Jiwa (selanjutnya disingkat ODGJ). Untuk membantu kita dalam memahami keterlibatan Gereja dalam persoalan kemanusiaan; yakni perannya bagi orangorang berkebutuhan khusus teristimewa ODGJ, maka saya mecoba mendalaminya dari beberapa perpektif ajaran Gereja dan juga melalui terang biblis. Beberapa ajaran dari KV II dan wawasan biblis tertentu akan saya pilih sebagai pendasaran teologis untuk memahami keterlibatan Gereja dalam persoalan kemanusiaan; berpastoral untuk Orang dengan Gangguan Jiwa.

Berteologi apalagi berpastoral selalu menuntut konteks tertentu. Tidak ada teologi tanpa konteks, maka tidak ada pula berpastoral tanpa konteks. Teologi kontekstual menjadikan konteks local sebagai medan berteologi. Konteks berkaitan erat dengan seluruh medan perjuangan manusia di dunia. Berteologi dan berpastoral menuntut Gereja untuk selalu menjadi bagian dari kehidupan manusia. Medan pastoral yang tampan ataupun tidak tampan, yang menarik atau tidak menarik, yang menantang atau tidak menantang tidak bisa dihindari oleh Gereja. Panggilan Gereja adalah panggilan yang menuntut keterlibatan. Gereja yang tidak terlibat dalam kompleksitat kehidupan manusia hanya akan menggali kubur bagi dirinya sendiri.

Persoalan ODGJ adalah persoalan kemanusiaan universal. Persoalan ini adalah juga merupakan persoalan Gereja. Karena ini merupakan persoalan Gereja maka itulah konteks berteologi, konteks berpastoral. Masalah ODGJ merupakan medan yang tampan untuk berteologi. Terhadap konteks ini gereja mesti terlibat.

Kita bersyukur bahwa umat Allah yang merupakan bagian dari gereja mengambil bagian dalam usaha memperhatikan ODGJ. Kita bersyukur pula bahwa ada kelompok-kelompok dalam masyarakat berjuang dengan membuat gerakan dengan membangun jejaring sosial tanpa memperhatikan sekat-sekat primordial seperti agama, suku, ras dan golongan. Mereka bahkan telah menginspirasi pemerintah dalam menumbuhkan kesadaran tentang pentingnya perhatian Negara terhadap ODGJ, karena ODGJ juga adalah warga Negara Indonesia. 


\section{Pandangan Biblis tentang Orang dengan Ganguan Jiwa}

\section{(Luk. 8:26-39; Mat. 8:28-34; Mrk. 5;1-20)}

Kitab Suci menaruh perhatian yang serius terhadap masalah kemanusiaan. Kitab suci perjanjian Baru mengisahkan mukjizat penyembuhan yang dilakukan Yesus kepada orang yang kerasukan setan. Misalnya teks Lukas yang berkisah tentang Yesus mengusir roh jahat dari orang Gerasa. Amat jelas terlihat bahwa pemasungan orang dengan gangguan jiwa bukan hanya terjadi pada zaman ini. Di zaman Yesus pun perlakuan terhadap ODGJ tak jauh beda dengan yang dibuat oleh masyarakat kita sekarang ini: "ia berkata demikian sebab Yesus memerintahkan roh jahat itu keluar dari orang itu. Karena sering roh-roh itu menyeret dia, maka untuk menjaganya ia dirantai dan dibelenggu, tetapi ia memutuskan segala pengikat itu dan ia dihalau oleh setan itu ke tempat yang sunyi". Kutipan di atas menunjukkan bahwa persolan perlakuan terhadap ODGJ adalah persolan klasik; dirantai/dibelenggu.

Setelah Yesus tiba di seberang, ia ditemui oleh seorang laki-laki yang menderita penyakit jiwa. Ia masygul-kegila-gilaan yang dibarengi kerasukan setan. Dia memberikan pengertian yang aneh mengenai siapa Yesus. Pada zaman itu penyembuhan terhadap sakit jiwa tidaklah dikenal selain dari mengurung mereka dalam tahanan yang paling ketat. Tapi rupanya pria ini sudah luput dari aneka macam pengekangan. Ia didorong oleh sekian banyak dorongan hati yang saling bertentangan, sehingga dia merasa bahwa dirinya dirasuki oleh suatu pasukan setan yang berjumlah 5000. Yesus berbelas kasih terhadap orang tersebut dan membebaskan dia dari setansetan dengan memasukan setan ke dalam babi-babi. Kenapa mesti dimasuki ke babi-babi? Jawabannya bahwa, seorang manusia lebih berharga dari seekor babi atau sekumpulan babi (Yayasan Komunikasi Bina Kasih, 1983: 220). Maka Yesus sengaja memasukan setan itu ke babi-babi.

Di sisi lain orang-orang yang ada di sekitar peristiwa pembunuhan itu marah dan meminta Yesus untuk segerah pergi dari sana. Pikiran mereka telah disesaki dengan ketakutan. Pertama, takut ODGJ yang telah disembuhkan itu kambuh lagi, Kedua, mereka takut karena peristiwa supra-natural itu. Sesuatu yang tidak biasa mereka lihat. Tetapi sikap ini pada gilirannya menutup mata mereka untuk melihat kasih karunia Allah yang sedang bekerja dalam diri pria Gerasa yang disembuhkan dari penyakit kejiwaan itu.

Nampak sekali suatu pola hidup perkotaan yang lebih mementingkan kepentingan ekonomi daripada kepentingan kerohanian. Mereka merasa bisnis babi mengalami kerugian karena banyak babi yang kerasukan setan dan harus terjun ke jurang. Seperti juga setan-setan itu, penduduk kota Gerasa tidak suka campur tangan Allah dalam kesembuhan lelaki di Gerasa yang menderita gangguan jiwa dan kerasukan setan (Yayayasan Komunikasi Bina Kasih, 1983: 83).

Kisah ini secara paralel muncul pula dalam Markus 5:1-20. Markus secara lebih lengkap mengurai proses terapi yang dibuat Yesus terhadap pria Gerasa ini. Mula-mula dia menjadi pasien dengan keluhan gangguan jiwa yang tidak bisa diatasi, bahkan dirantai saja sudah tidak mempan lagi. Kemudian sepanjang hidupnya penuh penderitaan, sebab tidak kenal istirahat atau 
tidur, dia selalu menjerit dan disiksa tanpa henti. Dilanjutkan dengan, pengenalan akan kewibawaan Yesus merupakan suatu gejala umum dalam kasus-kasus semacam ini. Lebih lanjut, terapi atau tindakan medis yang dibuat Yesus tidak berbelit-belit. Tidak pake SOP yang berbelitbelit, dengan satu perintah saja setan-setan itu keluar. Keteranganm psikologis macam manapun tidak mampu menjelaskan secara tuntas tentang problem kejiwaan ini. Bagi para psikiater orang ini tidak lebih hanya sebagai suatu kasus (Yayasan Komunikasi Bina Kasih, 1983: 147).

Perlakuan dan tindakan penanganan terhadap ODGJ hampir sama di beberapa tempat di daerah kita: dibiarkan berkeliaran di jalanan atau kalau berbahaya dipasung atau dirantai bahkan bertahun-tahun. Masalah pemasungan terhadap ODGJ kerapkali berasal dari kecenderungan manusia untuk mementingkan dirinya atau dalam istilah teologis berasal dari kedosaan manusia (dosa egoisme). Salah satu problemnya disebabkan oleh praktek ketidakadilan sebagaimana terjadi dalam bentuk peminggiran terhadap hak-hak ODGJ. Mereka dipasung kebebasannya hanya karena mereka dinilai berbahaya bagi ketentraman hidup masyarakat.

Masalah-masalah kemanusiaan seperti diangkat dalam uraian biblis di atas membawa dampak pada terciptanya kondisi-kondisi hidup yang tidak layak dan membawa manusia jauh dari cita-cita keselamatan. Sesungguhnya pandangan Kristen tentang keselamatan erat hubungannya dengan masalah ini. Pada situasi seperti ini martabat manusia ditendang ke titik nadir dan solidaritas serta sikap altruistis tidak mendapat tempat sebab egoisme mengalir deras dalam diri manusia.

Dalam hidup menggereja, pewartaan mengenai belas kasih kadang-kadang hanya menjadi penghias mimbar Sabda. Kotbah tentang hidup solider dengan orang miskin, menderita, ODGJ menjadi semacam dongeng penghantar tidur bagi umat yang katanya beriman. Di titik ini kita menemukan bahwa ada jarak antara permainan kata-kata biblis dengan aksi yang menyata dalam praksis. Apa yang menjadi bahan kotbah di mimbar Sabda tidak diteruskan oleh umat beriman dalam kehidupan nyata tetapi berhenti di pintu Gereja. Kotbah tentang perhatian terhadap orangorang yang dipinggirkan dalam kehidupan sosial (baca: ODGJ) di mimbar Sabda menjadi semacam suara sumbang. Hasilnya bahwa masalah kemanusiaan ini tetap menjadi masalah klasik.

\section{Martabat Orang dengan Gangguan Jiwa}

Setiap orang yang dilahirkan ke dunia memiliki martabat yang sama. Martabat yang dimiliki membuat manusia berharga entah bagi dirinya sendiri, berharga di hadapan sesama, apalagi di hadapan Tuhan penciptanya. Martabat manusia tidak pernah memandang status sosial, keadaan ekonomi, atau kondisi fisik dan seseorang. Artinya siapapun yang namanya manusia, ia memiliki martabat. Martabat adalah suatu datum, pemberian.

Lebih dalam dari itu manusia diciptakan hampir setara dengan Allah. Manusia adalah gambaran Allah atau citra Allah. Segalah sesuatu diarahkan kepada manusia sebagai pusat dan 
puncak. Adapaun KS mengajarkan bahwa manusia diciptakan menurut gambar Allah, ia mampu mengenal dan mengasihi penciptanya; oleh Allah manusia ditetapkan sebagai tuan atas semua makhluk di dunia ini untuk menguasainya dan menggunakannya sambil meluhurkan Allah (GS.12).

Filsuf beraliran personalisme abad 20 seperti Karol Wojytla (Paus JP II), menegaskan tentang manusia sebagai pribadi (person). Melalui mazhab personalisme, Wojytla menegaskan bahwa manusia adalah pribadi yang tak tergantikan oleh apa dan siapapun, manusia itu adalah pribadi yang unik apapun kondisi yang dialaminya. Pemikiran Karol Wojytla ini turut mempengaruhi lahirnya dokumen Gereja tentang sikap hormat terhadap pribadi manusia yang mengatakan:

Beranjak kepada konsekuensi-konsekuensi praktis yang cukup mendesak, Konsili, menekankan sikap hormat terhadap manusia sehingga setiap orang wajib memandang sesamanya, tak seorang pun terkecualikan, sebagai "dirinya yang lain" terutama mengindahkan peri hidup mereka beserta upaya-upaya yang mereka butuhkan untuk hidup secara layak, supaya jangan meniru orang kaya, yang sama sekali tidak mempedulikan Lazarus yang miskin (GE.27).

Penegasan ini adalah amanat bagi dunia pada umumnya dan kepada gereja khususnya bahwa martabat pribadi manusia perlu dijamin kelangsungannya oleh siapapaun yang berkehendak baik. Tiap orang bertanggung jawab mengusahakan agar martabat sesama tidak dicederai, didiskriminasi atau dilecehkan hanya karena keadaan fisik maupun psikis yang kurang beruntung. Lebih lanjut, para Bapa Konsili juga tidak hanya sekedar mengumandangkan seruan moral tetapi mereka juga menegaskan tentang upaya konkret dari manusia untuk mengusahakan hidup yang layak bagi sesamanya. Apa yang diamanatkan oleh Para bapa Konsili berangkat dari suatu kesadaran tentang kerapuhan manusia yang bisa dengan gampangnya membawa mudarat bagi sesamanya. Hal ini nyata dalam praktek diskriminasi, peminggiran, dan pelcehan terhadap kelompok manusia tertentu.

Manusia dengan susah payah membangun peradaban, tetapi seringkali mencedarinya sendiri. Sebagai salah satu usaha membangun peradaban, manusia dengan amat sulit membidani lahirnya kesadaran tentang penghormatan atas martabat pribadi manusia, tetapi dia sendiri yang membunyikan lonceng kematian bagi peradaban. Dia sendiri yang mencabut martabat pribadi sesamanya oleh karena situasi yang mungkin tak dapat diatasi sendiri, atau karena ketidakpedulian terhadap kebutuhan sesamanya. Terhadap situasi seperti ini para Bapa Konsili menegaskan bahwa situasi ini adalah ikhtiar melawan kehidupan sendiri dan merupakan sebuah kekejian:

Apapun yang melanggar keutuhan pribadi manusia, seperti pemenggalan anggota badan, siksaan yang ditimpakan pada jiwa atau raga, usaha-usaha paksaan psikologis, apapun yang melukai martabat manusia, seperti kondisi-kondisi hidup yang tidak layak manusiawi, pemenjaraan yang sewenang-wenang, pembuangan orang-orang...dan tidak diperlakukan sebagai pribadi-pribadi yang bebas dan bertanggung jawab: semua itu dan hal-hal lain merupakan perbuatan yang keji (GE. 27) 
Selain itu, dalam bingkai pemikiran tentang penegakkan hak asasi manusia (AG 12): "misi Gereja dijiwai oleh cinta kasih kristiani yang ditujukkan kepada semua orang tanpa pandang bulu, yakni Gereja membela hak asasi manusia, terlibat dengan mereka yang miskin, menegakkan keadilan dan perdamaian, memajukan ekonomi, dan meletakan kehidupan sosial secara layak dan benar.

Di tempat lain, pemikiran Yohanes Paulus II turut memberi arah dasar bagi teologi sosial. Teologi sosial dari Yohanes Paulus II adalah "teologi politik", yaitu refleksi iman yang berpangkal dan bertujuan pada usaha untuk membangun hidup manusia. Ikut dalam usaha itu adalah tugas Gereja: tugas Gereja adalah tugas teologis-kristologis, bukan sosial-politis. Gereja harus mewartakan Injil tentang martabat dan tujuan manusia yang diterima dalam Kristus; maka kegiatan Gereja biarpun adalah non-politik, namun tidak dapat tidak berpengaruh politik. Gereja mempunyai pengaruh dalam bidang kemasyarakatan karena dengan pewartaannya ikut secara konkret dalam proses penyadaran manusia. Maka tugas gereja bersifat profetis yaitu melibatkan diri dalam perjuangan hak-hak manusia, khususnya hak kaum miskin dan tertindas tetapi tanpa menggunakan kuasa apalagi kekerasan (Kiesser, 1992:75).

Dalam kaitan dengan ini maka keterlibatan kelompok sosial yang diprakarsai oleh tokohtokoh Gereja atau umat Katolik perlu dipahami dalam konteks ini. Kalau keterlibatan kelompok sosial karitatif dalam pembebasan ODGJ mesti beririsan atau bersentuhan dengan politik maka itu sebuah konsekuensi amat logis dari sebuah praksis teologi sosial. Bahkan aksi kepedulian Gereja kepada ODGJ menginspirasi banyak orang untuk peduli, termasuk tokoh-tokoh politik dan birokrasi yang baru sadar bahwa perhatian kepada ODGJ adalah bagian dari tugas Negara yang tidak bisa dihindari atau dialihkan kepada pihak lain. Jika praktek pembebasan itu dilakukan dengan kekerasan dan tendensi untuk mempertontonkan kekuasaan maka itu bukan ciri perjunagan Gereja. Tetapi jika mereka melakukan dengan damai maka itu merupakan ciri khas perjuangan Gereja dan sepantasnya direspon dengan cara yang bermartabat.

\section{Gereja yang Tidak Boleh Diam terhadap Persoalan ODGJ}

Apapun tantangannya Gereja tidak boleh diam terhadap persoalan ODGJ. Sikap diam Gereja terhadap persoalan ODGJ tidak sesuai dengan amanat Yesus Kristus. Yesus berani melawan kebiasaan buruk penduduk kota Gerasa yang merantai atau membelenggu ODGJ. Gereja mesti berperan dalam usaha pembebasan ODGJ. Paus Paulus VI dalam Evangelium Nuntiandi menegaskan bahwa dewasa ini, usaha untuk memberi kesaksian tentang Allah, bapa bagi semua orang, dan tentang penyelamatan dalam Yesus Kristus tidak dapat dipisahkan dari usaha untuk pembebasan manusia.

Gereja melalui para agen pastoral sepantasnya memperhatikan secara serius keseimbangan antara pelayanan rohani dan pelayanan sosial karitatif. Para agen pastoral tidak hanya memperhatikan upacara liturgis dan sakramental tetapi juga memberi perhatian kepada pelayanan sosial karitatif. Tepat seruan kritis John Prior: 
Kenyataannya, banyak orang yang kini aktif dalam LSM akar rumput tidak lagi aktif dalam kehidupan paroki. Paroki tinggal diam seribu bahasa terhadap apa yang penting dalam kehidupan dan perjuangan mereka akan keadilan sosial. Jika upacara-upacara liturgis serta ziarah dan perarakan keagamaan terlepas dari keprihatinan kemanusiaan, maka agama yang demikian akan sealiran dengan agama kenisah dan kaum farisi. Agama yang demikian hanya akan membuahkan konsep pada kalangan LSM pemerhati akar rumput, bahwa Allah yang diwartakan adalah allah yang bersekongkol dengan korupsi, kemunafikan, diskriminasi, seksisme, atau kekerasan dalam rumah tangga (Prior, 2010: 47).

Apa yang dikritisi oleh John M. Prior menjadi fakta tak terbantah tentang model karya pelayanan saat ini. Terlalu fokus terhadap program pelayanan liturgis-sakramental dan mengabaikan pelayanan sosial yang dilandasi cinta kasih Kristiani. Karena itu, umat membutuhkan pewarta yang mampu mengurusi kebutuhan-kebutuhan pastoral biasa dari suatu jemaat, namun juga membutuhkan para pewarta yang memiliki semangat profetis.

Namun bagaimana mempertahankan originalitas keterlibatan Gereja dalam usaha perkembangan yang menggerakan seluruh dunia? Pertama, dalam rangka pewartaan dan hidup Gereja, semua usaha pembebasan mesti dipandang dalam rangka pewartaan keselamatan yang transenden (no. 32), yakni bukan sebagai pemenuhan kebutuhan melainkan sebagai pengarahan kepada Allah yang semakin besar (no.34). Pembebasan itu menyangkut seluruh dimensi hidup manusia. Kedua, usaha pembebasan adalah usaha yang digalakan tanpa kekerasan (no.37) (Kiesser, 1992: 200-201). Tentang hal ini kelompok KKI meskipun terdiri dari orang-orang dengan pelbagai latar belakang agama, tetapi mereka menunjukkan ciri pembebasan tanpa kekerasan.

Keberpihakan, kepedulian terhadap ODGJ harus menjadi salah satu pilihan dasar dan fokus pastoral Gereja. Pilihan untuk berpihak kepada orang-orang yang lemah seperti kepada ODGJ bukan soal suka atau tidak suka, bukan soal minat atau tidak minat, bukan soal menantang atau tidak menantang tetapi lebih dalam dari itu adalah pilihan mendasar (optio fundamentalis) dan mendesak dalam konteks Gereja Lokal, sekaligus merupakan sebuah imperatif teologi. Kesadaran ini mesti tetap berdiri tegak agar kelompok-kelompok yang diprakrsai oleh tokohtokoh dalam gereja seperti imam dan awam tidak menjadi kelompok musiman; panas membara sewaktu-waktu, meredup di waktu yang lain, bahkan bisa saja menghilang. Perlu dipikirkan sebuah reksa pastoral bagi orang berkebutuhan khusus seperti ODGJ. Beberapa anjuran yang mungkin bisa dipertimbangkan dalam sebuah reksa pastoral adalah mulai dengan: pertama, penyadaran (konstientisasi) kepada umat, keluarga bahwa ODGJ adalah manusia yang bermartabat, dan martabatnya itu dijamin tanpa melihat gangguan kejiwaan yang dialaminya. Konkretnya melalui kegiatan katekese, gerakan sosial keagamaan. Kedua, usaha pendampingan oleh seluruh elemen masyarakat yang terkait dengan ODGJ.

Perhatian kepada ODGJ harus menjadi sebuah gerakan sosial seluruh elemen masyarakat. Pemerintah wajib mengambil bagian dalam pembebasan ODGJ. Kewajiban Negara untuk memelihara, memperhatikan dan mengusahakan proses penyembuhan entah secara fisik maupun psikologis. Pemerintah perlu melaksanakan penyadaran kepada keluarga ODGJ tentang 
perlakuan yang layak bagi mereka. Presentase ODGJ begitu besar seharusnya membuat para anggota legislatif perlu memikirkan sebuah Perda untuk menangani ODGJ. Sehingga upaya yang telah dimulai oleh tokoh-tokoh Gereja dan umat beragama lainnya yang terlibat dalam pembebasan ODGJ menjadi inspirasi bagi pemerintah dan DPRD untuk menciptakan kebijakan politik yang berpihak kepada ODGJ. Dengan demikian Negara turut mengambil bagian dalam mensejahterakan masyarakatnya.

\section{Penutup}

Gereja perlu terlibat dalam persoalan ODGJ. Keterlibatan Gereja adalah pilihan mendasar (optio fundamentalis). Gereja yang dimaksudkan bukan hanya pada hirarki tetapi seluruh umat Allah yang sedang berziarah ke rumah Bapa. Maka bicara tentang tanggung jawab Gereja terhadap ODGJ berarti bicara tentang tanggung jawab seluruh umat Katolik dan siapapun yang berkehandak baik. Umat beriman yang terlibat dalam gerakan sosial karitatif terhadap ODGJ mesti memahami bahwa perjuangan mereka adalah tindakan mengambil bagian dalam tugas pastoral Gereja. Jadi umat yang terlibat dalam mengurus ODGJ tidak pernah berjuang sendirian.

Gereja dalam hal ini hirarki juga turut dan wajib memliki pemahaman dan tindakan nyata terhadap ODGJ. Sikap dan seruan-seruan moral hirarki Gereja amat penting agar menjadi daya dorong bagi legitimasi perjuangan Gereja dan umat beriman. Hirarki Gereja mempunyai posisi strategis dalam perjungan mengatasi problem ODGJ. Posisi yang stategis ini menuntut tindakan yang strategis pula untuk mendorong dirinya sendiri, umat beriman, pihak swasta dan pemerintah agar memiliki perhatian dan tindakan nyata bagi para ODGJ. Paling kurang agar seluruh elemen masyarakat memliki pandangan yang sama tentang martabat pribadi para ODGJ dan juga agar semua orang bisa mengusahakan solusi yang manusiawi dan bermartabat dalam mengatasi problem ODGJ.

\section{Kepustakaan:}

\section{Dokumen Gereja}

Dokumen Konsili Vatikan II, Gaudium et Spes. Penerj.Hardawirayana. Jakarta:, Obor, 1993.

Komisi Kepausan untuk Keadilan dan Perdamaian, Kopendium Ajaran Sosial Gereja. Maumere: Ledalero, 2009.

Seri Dokumen Gereja, Evangelium Nuntiandi, Penerj. P. Turang, Jakarta: DOKPEN KWI, 1988.

Seri Dokumen Gereja, Solicitudo Rei Sosialis, Penerj. P. Turang, Jakarta: DOKPEN KWI, 1988.

Yayasan Komunikasi Bina Kasih, Tafsir Alkitab Masa Kini, Cet-3. Jakarta: BPK Gunung Mulia. 1983.

\section{$\underline{\text { Buku-buku }}$}


Banawiratma, J.B, (Ed.). Aspek-Aspek Teologi Sosial. Yogyakarta: Kanisius, 1992.

Dister, Nico Syukur. Teologi Sistematik. Yogyakarta: Kanisius, 2004

John M. Prior. Menjebol Jeruji Prasangka, Membaca Alkitab dengan Jiwa. Maumere: Ledalero, 2010.

Kemenkes. "Peran Keluarga dalam Kesehatan Jiwa Masyarakat.” Jakarta: Biro Komunikasi dan Pelayanan, Kemenkes. 2016. Diakes tanggal 12 Juli 2018 melalui www. Depkes. go.id.

Kieser, B. Solidaritas 100 tahun ajaran sosial Gereja. Yogyakarta: Kanisius, 1992.

Kirchberger, Georg. Allah Menggugat: Sebuah Dogmatik Kristiani. Maumere, 2007. 